\title{
Internal Factors of Dividend Policy at the Firm Level: A Case Study of Lenovo Annual Report
}

\begin{abstract}
Yuhan $\mathrm{Cao}^{* 1}$
${ }^{1}$ Dongbei University of Finance and Economics

*Corresponding author. Email: yc01448@surrey.ac.uk

ABSTRACT

This paper examines Lenovo's 1617 Annual Report to analyze internal factors of the dividend policy. Dividend policy illustrates relevant events like whether corporations issue dividends, about what percentage of dividends would be issued and when would be the issuing date. Virtually, the main concept of dividend issuance is to distribute corporations' net profit, which could affect both shareholder's ownership and retained earnings. Now that dividends are vital to managers and investors, what factors can affect dividend payout?

Previous studies have already shown that several external determinants matter in dividend payout. This paper mainly reports internal factors including short-term liquidity, long-term solvency, profitability and efficiency. Moreover, unlike previous articles which used experimental data analysis, this paper uses ratio analysis to present the relationship between each determinant and dividend payout. The paper illustrates that all these internal factors have positive relationships with the dividend payout ratio.
\end{abstract}

Keywords: Liquidity, profitability, dividend policy, ratios, efficiency

\section{INTRODUCTION}

In 1956, John Linter established the modern foundation of dividend policy[8]. Dividend policy refers to the payout policy that a firm follows in determining the size and pattern of distributions to shareholders over time[7]. According to Yan[9], dividend policy plays an important role in the future development of the company, whether it can stabilize and attract more investors. From the perspective of investors, the implementation of dividend policy also determines an important way for investors to obtain remuneration. As Baker et al. note[3], dividends remain one of the greatest conundrums of modern finance.

On the broader aspect, some external incentives such as Inflation and Gross Domestic Production(GDP) could make a difference to people who make decisions about dividend payout. For instance, during inflationary periods, capital generated from operating activities is less valuable to cover liability and it is sensible to maintain more dividends in the company rather than in the shareholders. Besides, when GDP is higher, it means that there would be more opportunities for companies to reinvest their capital into an open market, which is more reasonable than to allocate dividends among stockholders[2]. Obviously, not only the macro- environment can affect dividend policy, but the internal factors can make a profound impact in deciding dividend issuance. This statement will be explained more explicitly by analyzing liquidity, profitability and efficiency perspectives with several accounting ratios, and by calculating data from Lenovo Annual Report.

\section{SHORT-TERM LIQUIDITY}

In capital markets, liquidity is an essential indicator of financial performance within the company. If the company could overlap its debts, it will be considered as a company with good liquidity, causing increase of stock value[7]. Generally, companies assess their liquidity on two aspects which are short-term liquidity and long-term solvency. First, when it comes to short term, relevant ratios on how to calculate liquidity are current ratio and quick ratio.

Current Ratio $=$ current assets / current liabilities (1)

Quick Ratio = current assets - inventory / current liabilities (2)

The main purpose of these two formulas is to compare current assets with current liabilities to evaluate the ability of short-term assets to cover short-term liabilities. In business trade, current assets generate cash from sales of 
inventory and from trade receivables paying what they owe and as a result, this cash is then used to meet current liabilities as they become due for payment. The only difference between these two ratios is the consideration of inventory, which is ambiguous to be regarded as current assets because sometimes inventory is assumed to be difficult to sell and so not easily convertible into cash. Still, this assumption may not be realistic since inventory turnover speed depends on each entity's industrial sector and the production of goods to order.

Working capital $=$ current assets - current liabilities

Occasionally, the working capital ratio is also a numerical tool to look at how quickly inventory is sold, how quickly trade receivables are turned into cash and how quickly trade payable are paid. But because it is an absolute number equals to current assets minus current liabilities, it is not convenient to compare the short-term liquidity of enterprises with different scales.

According to Josephat[6], a weak corporate liquidity position implies a less sufficient cash dividend due to a cash shortage. Corporations with higher short-term liquidity signify a rapid cash turnover, which is good news for investors because the dividend payout ratio would be higher. In other words, there is a positive relationship between liquidity and dividend payout frequency.

\begin{tabular}{lrr} 
Current liabilities & $\begin{array}{r}2017 \\
\text { US } \$ 000\end{array}$ & US $\$$ '000 \\
\hline Trade payables & $\mathbf{5 , 6 4 9 , 9 2 5}$ & $\mathbf{4 , 2 6 6 , 6 8 7}$ \\
Notes payable & $\mathbf{8 3 5 , 6 1 3}$ & 234,661 \\
Derivative financial liabilities & $\mathbf{6 7 , 2 8 5}$ & $\mathbf{1 5 0 , 8 6 4}$ \\
Other payables and accruals & $\mathbf{1 0 , 0 0 4 , 6 1 4}$ & $\mathbf{8 , 3 0 5 , 8 4 4}$ \\
Provisions & $\mathbf{8 7 3 , 4 0 5}$ & $\mathbf{1 , 1 5 7 , 2 5 7}$ \\
Deferred revenue & $\mathbf{5 8 6 , 5 3 6}$ & $\mathbf{7 1 0 , 1 6 4}$ \\
Income tax payable & $\mathbf{2 4 6 , 4 6 5}$ & 188,968 \\
Borrowings & $\mathbf{7 0 , 0 0 3}$ & $\mathbf{7 4 5 , 8 1 5}$ \\
\hline
\end{tabular}

Figure 1 Current liabilities of Lenovo in 2016 and 2017

\begin{tabular}{lrr} 
& 2017 & 2016 \\
Current assets & US\$’000 & US\$’000 \\
\hline Inventories & $\mathbf{2 , 7 9 4 , 0 3 5}$ & $2,637,317$ \\
Trade receivables & $\mathbf{4 , 4 6 8 , 3 9 2}$ & $4,403,507$ \\
Notes receivable & $\mathbf{6 8 , 3 3 3}$ & 130,718 \\
Derivative financial assets & $\mathbf{5 3 , 8 0 8}$ & 27,021 \\
Deposits, prepayments and other receivables & $\mathbf{4 , 3 3 3 , 3 5 1}$ & $3,548,760$ \\
Income tax recoverable & $\mathbf{1 9 9 , 1 4 9}$ & 140,237 \\
Bank deposits & $\mathbf{1 9 6 , 7 2 0}$ & 152,336 \\
Cash and cash equivalents & $\mathbf{2 , 7 5 4 , 5 9 9}$ & $1,926,880$ \\
\hline & $\mathbf{1 4 , 8 6 8 , 3 8 7}$ & $12,966,776$ \\
\hline
\end{tabular}

Figure 2 Current assets of Lenovo in 2016 and 2017

From the above charts, current ratio of Lenovo in 2016 and 2017 was 0.81 and 0.82 respectively. Quick ratio was 0.66 in 2016, which was the same in 2017.
Generally speaking, Lenovo has maintained its liquid position. 


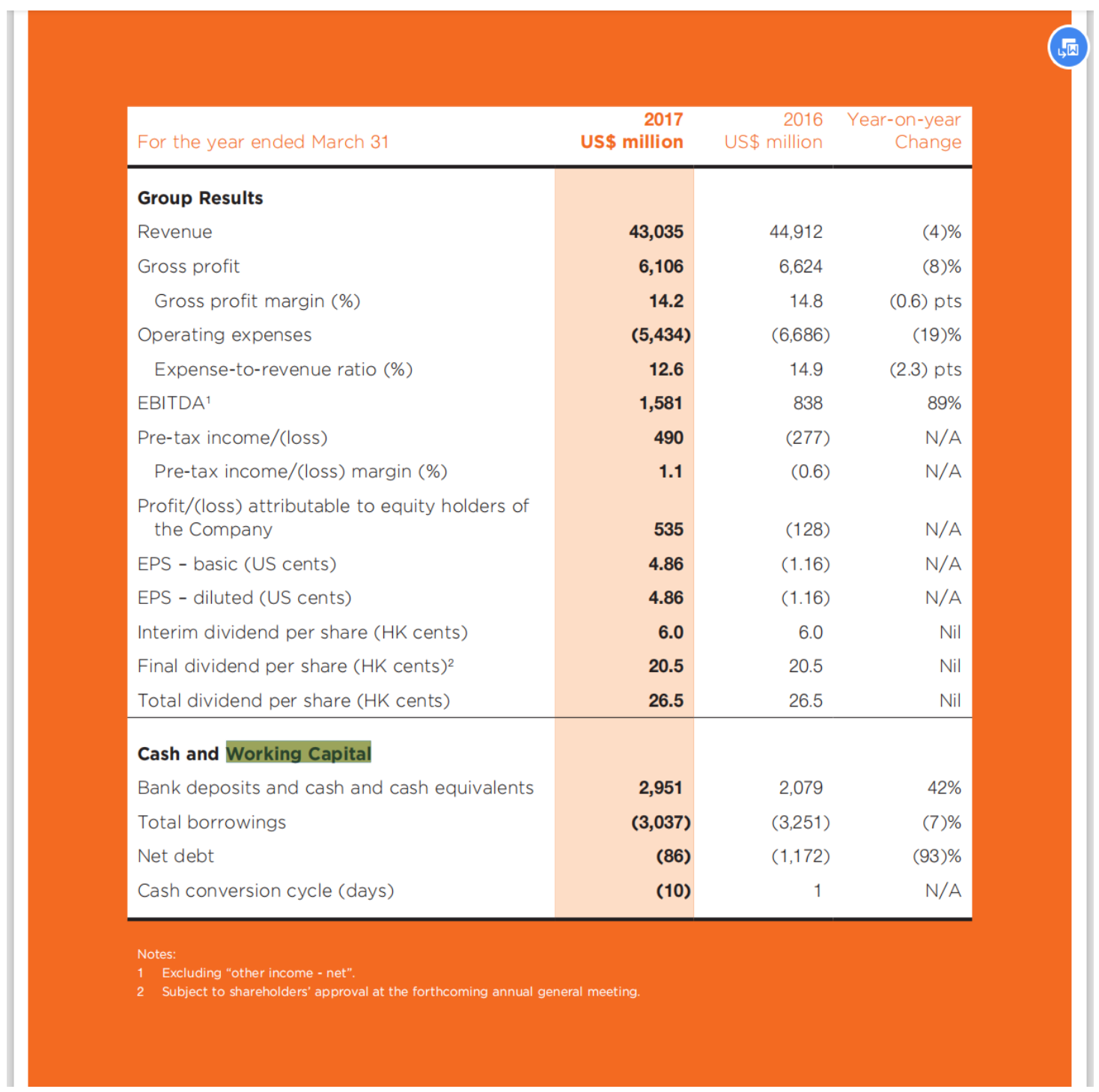

Figure 3 Lenovo financial highlights

Lenovo highlighted this diagram in its annual report with a few vital data. For instance, working capital was explained in another way, net debt. Comparing to 2016, net debt rose mainly because cash, bank deposit and cash equivalents increased from 2,079 to 2,951, which signified that Lenovo had abundant cash flows.

\section{LONG-TERM SOLVENCY}

Second, any evaluation of an entity's ability to survive must consider long-term solvency. Almarzoqi states that the company would have financial solvency risks if they cannot meet maturing obligations because of a negative net worth[1]. In other words, it is an organization's ability to meet the interest on and repayment of long-term, non-current liabilities as they fall due. To some extent, a company's long-term performance is closely related to financial risk during an operating period.

Debt Ratio $=$ total liabilities $/$ total assets (4)

Gearing Ratio = total liabilities / total equity (5)

Giving the debt ratio as an example, it can be easily calculated as total liabilities divided by total assets. Once this ratio becomes higher, it means that the sources of the capital are mainly from debt financing not equity financing and there will be longer repayment for companies to work out which is a threat to the life span. Apart from that, the gearing ratio can also be calculated to measure long-term liquidity. 


\begin{tabular}{lrrr} 
& $\begin{array}{r}\mathbf{2 0 1 7} \\
\text { US\$ million }\end{array}$ & $\begin{array}{r}2016 \\
\text { US\$ million }\end{array}$ \\
\hline Bank deposits and cash and cash equivalents & $\mathbf{2 , 9 5 1}$ & 2,079 \\
Less: total borrowings & $\mathbf{( 3 , 0 3 7 )}$ & $(3,251)$ \\
\hline Net debt position & $\mathbf{( 8 6 )}$ & $(1,172)$ \\
\hline Total equity & $\mathbf{4 , 0 9 5}$ & 3,026 \\
\hline Gearing ratio & $\mathbf{0 . 7 4}$ & 1.07 \\
\hline
\end{tabular}

Figure 4 Capital risks management

A gearing ratio is calculated by dividing total debt by total equity. If the outcome is too high, that means the company is experiencing or will face financial risk. As the chart is shown above, even though the gearing ratio in 2017 is less than that in 2016, Lenovo had high financial distress since liability accounted for more than 50 percent of equity. Generally, owners scrutinize a company's gearing ratios because they reflect the levels of risk involved with the company.

In a word, corporations with higher liquidity are more likely to achieve good performance and have capital surplus to be allocated to shareholders as dividends.

\section{PROFITABILITY}

As for profitability, it is common for companies to use profit margin, return on asset or return on equity as a way of assessing how much sales revenues, total assets or total equity can convert into a unit of net income respectively.

Return on Asset $(\mathrm{ROA})=$ net income / total assets (6)

Return on Equity $(\mathrm{ROE})=$ net income / total equity $(7)$

Profit margin $=$ net income $/$ sales revenue $(8)$

The higher these three ratios, the companies will gain more profits and then tend to issue more dividends to investors. On the other hand, a firm's net earnings are an important factor influencing dividend payments[8]. An unprofitable company cannot continue issuing dividends because they must be paid from net income. Other proponents also agree that the influence of profitability is fundamental to the dividend payout ratio. He [5] concludes that corporate dividend policy usually change with the changes in its past profits, current profits, and expected futureprofits.

\begin{tabular}{|c|c|c|c|}
\hline For the year ended March 31 & $\begin{array}{r}2017 \\
\text { US\$ million }\end{array}$ & $\begin{array}{r}2016 \\
\text { US\$ million }\end{array}$ & $\begin{array}{r}\text { Year-on-year } \\
\text { Change }\end{array}$ \\
\hline \multicolumn{4}{|l|}{ Group Results } \\
\hline Revenue & 43,035 & 44,912 & (4)\% \\
\hline Gross profit & 6,106 & 6,624 & (8)\% \\
\hline Gross profit margin (\%) & 14.2 & 14.8 & $(0.6)$ pts \\
\hline Operating expenses & $(5,434)$ & $(6,686)$ & (19)\% \\
\hline Expense-to-revenue ratio (\%) & 12.6 & 14.9 & (2.3) pts \\
\hline EBITDA $^{1}$ & 1,581 & 838 & $89 \%$ \\
\hline Pre-tax income/(loss) & 490 & $(277)$ & N/A \\
\hline Pre-tax income/(loss) margin (\%) & 1.1 & $(0.6)$ & $\mathrm{N} / \mathrm{A}$ \\
\hline $\begin{array}{l}\text { Profit/(loss) attributable to equity holders of } \\
\text { the Company }\end{array}$ & 535 & $(128)$ & $\mathrm{N} / \mathrm{A}$ \\
\hline EPS - basic (US cents) & 4.86 & $(1.16)$ & N/A \\
\hline EPS - diluted (US cents) & 4.86 & $(1.16)$ & $\mathrm{N} / \mathrm{A}$ \\
\hline Interim dividend per share (HK cents) & 6.0 & 6.0 & Nil \\
\hline Final dividend per share (HK cents) ${ }^{2}$ & 20.5 & 20.5 & Nil \\
\hline Total dividend per share (HK cents) & 26.5 & 26.5 & Nil \\
\hline
\end{tabular}

Figure 5 Lenovo income statement 
Usually profit margin is a fundamental measurement for external investors to consider whether they would become a member of the company's shareholder. To some extent, the greater proportion of gross profit margin reflects the larger amount of net income, leading to more dividends payment. Focusing on the annual report, though the profit margin in 2017 was smaller than the previous year, earnings per share became higher than that in 2016 due to the relatively lower expenses and positive pre-tax income. Therefore, profitability should be analyzed via not only this profit margin ratio, but also other capital directions. After using several calculated ratios, a comprehensive examination on profitability could determine part of the dividend policy for the firm.

\section{EFFICIENCY}

Even if enterprises with higher profitability could generate more capital than the benchmarks, the time for them to generate an equal amount of cash is rather essential, which is called efficiency. In the financial environment, the cash conversion cycle is an important standard to measure the efficiency of an enterprise.

Cash Conversion Cycle $=$ inventory turnover + accounts receivable turnover - accounts payable turnover (9)

The cash conversion cycle measures both how quickly inventory is turned into trade receivables and how quickly trade receivables are turned into cash with which to meet trade payable. It looks at the amount of time needed to sell inventory, the amount of time needed to collect receivables, and the time the company affords to pay to its supplies[4]. The shorter the cash conversion cycle, the better working capital is being managed, the more ready cash is available to meet liabilities. If the cash conversion cycle equals zero, it means that this company does not need any conversion day and its efficiency maintains at a high level. However, it seems quite unrealistic in the real business world since corporations are not willing to use their earned money to pay for liabilities immediately. But still, the more rapid cash inflows marks the higher efficiency for the company to utilize residual capital to shareholders.

\section{CONCLUSION}

Three main internal reasons affect the company's dividend policy, which are liquidity, profitability, and efficiency respectively.

Firstly, the better the liquidity, the more substantial the dividend payout ratio is. liquidity consists of shortterm liquidity and long-term liquidity. There are three ratios related to short-term liquidity, current ratio, quick ratio, and working capital. By contrast, the quick ratio is the most accurate measure of liquidity because it excludes more time-sensitive inventories. The higher the quick ratio, the faster turnover of the cash, receivables, inventory, and other current assets will be. Therefore, more cash dividends or stock dividends can be distributed to shareholders.

There are two ratios related to long-term solvency, namely debt ratio and gearing ratio. Both ratios correlate with debt. When the liabilities become overwhelming, the value of the two ratios will increase, indicating that it is more difficult for the company to recover the debt through existing assets or equity. Meanwhile, it indicates that fewer dividends will fall into shareholders' hands. In general, liquidity is the most vital factor in the implementation of corporate dividend policy.

Secondly, profitability is one of the criteria. Companies that have been suffering loss for years are not willing to pay out surplus dividends to shareholders. There are three corresponding ratios, profit margin, return on asset and return on equity. Generally, the profit margin is the ratio that investors pay the most attention to. With a higher profit margin, more sales revenue will be converted into profits per unit and more dividends will be allocated among investors.

The last factor, efficiency, considers how quickly the cost of investing money can be transformed into assets and deposited in the company's accounts. The Cash Conversion Cycle describes how inventory can be liquidated more quickly to offset trade payable. If the company can obtain Cash or Cash equivalents more quickly, the dividend payout ratio will be higher. As a result, the dividend policy will become better.

Generally speaking, these three indicators are the internal factors that contribute to dividend policy at the firm level. If the company's operating liquidity, net earnings, and turnover speed are all prospecting, then the company's dividend policy must be flourishing.

\section{ACKNOWLEDGMENTS}

First and foremost, I would like to show my deepest gratitude to my teachers and professors in my university, who have provided me with valuable guidance in every stage of the writing of this thesis. Further, I would like to thank all my friends and roommates for their encouragement and support. Without all their enlightening instruction and impressive kindness, I could not have completed my thesis.

\section{REFERENCES}

[1] Almarzoqi, R., Naceur, S., Scopelliti, A. (2015) How does bank competition affect solvency, liquidity and credit risk? IMF Working Papers, Vol. 15 No. 210.

[2] Ante, D. Igor, Z. (2019) Internal factors of dividend policy in public firms in Bosnia and Herzegovina. 
Croatian review of economic, business and social statistics, 2019-12-01, Vol.5 (2), p.1-16

[3] Baker, H., Weigand, R., Johnson, D. (2015) Dividends and Dividend policy. Bingley: Emerald Publishing Limited.

[4] Goel, S (2015) Financial Ratios. New York: Business Expert Press.

[5] He, Z., Chen, X., Huang, W., Pan, R., Shi, J., Smith, T. (2016) External finance and dividend policy: a twist by financial constraints. Accounting \& Finance Dec2016, Vol. 56 Issue 4, p935-959. 25p. 6 Charts.

[6] Josephat, L., David, M. (2020) On an ongoing corporate dividend dialogue: Do external influences also matter in dividend decision? Cogent business \& management. 2020-01-01, Vol.7 (1), p.1787734.

[7] Nailul, M., Agus, S. (2020) The Moderating Role of Dividend Policy on The Influence of Liquidity, Profitability, Leverage, and Investment Opportunity Set Against Stock Return Registered in The Jakarta Islamic Index. http://jurnal.untagsmg.ac.id/index.php/fe/article/vie w/1553/1252

[8] Theophano, P., Sunil, P., Kean, O. (2012) Determinants of corporate dividend policy in Greece.

https://www.tandfonline.com/doi/full/10.1080/096 03107.2011 .639734

[9] Yan, X. (2017) The study of dividend policy. Times Finance. Cumulatively No.655 2017 No.03. 